Tropical Journal of Pharmaceutical Research May 2019; 18 (5): 1095-1100

ISSN: $1596-5996$ (print); 1596-9827 (electronic)

(c) Pharmacotherapy Group, Faculty of Pharmacy, University of Benin, Benin City, 300001 Nigeria.

\title{
Evaluating the antidiabetic and antioxidant properties of 5- benzyl-1,3,4-oxadiazole-2-thiol
}

\author{
Shaista Qamar ${ }^{1,2}$, Khalid Hussain ${ }^{1 *}$, Nadeem I Bukhari ${ }^{1}$, Sabahat Z Siddique ${ }^{3}$, \\ Aziz-ur-Rehman ${ }^{3}$, Muhammad A Abbasi ${ }^{3}$, Sajida Parveen ${ }^{1}$, Abida Latif ${ }^{1}$, Abida \\ Qamar $^{1}$, Ejaz Ali ${ }^{1}$, Naureen Shehzadi ${ }^{1}$, Muhammad Islam ${ }^{1}$, Surriya Naheed ${ }^{1}$ \\ ${ }^{1}$ Punjab University College of Pharmacy, University of the Punjab, Allama lqbal Campus, ${ }^{2}$ Institute of Pharmaceutical Sciences, \\ University of Veterinary and Animal Sciences, ${ }^{3}$ Department of Chemistry, Government College University, Lahore-54000, \\ Pakistan
}

*For correspondence: Email: khussain.pharmacy@pu.edu.pk, hussain_761@yahoo.com; Tel: +92-4299211617

\begin{abstract}
Purpose: To evaluate 5-Benzyl-1,3,4-oxadiazole-2-thiol (OXPA) for antidiabetic and antioxidant properties.

Methods: Antidiabetic activity was evaluated using three in vitro models, glucose uptake by yeast cells, alpha amylase inhibition assay and hemoglobin glycosylation inhibition assays. Antioxidant potential was determined by DPPH radical scavenging, reducing power and lipid peroxidation assays.

Results: OXPA showed antidiabetic activity in all the three models. The activity of the compound was comparable with that of metronidazole in glucose uptake by yeast cells, but the alpha amylase inhibition activity of the compound was slightly lower than that of acarbose, whereas the hemoglobin glycosylation inhibition activity of the compound was higher than that of vitamin E. DPPH free radical and hydrogen peroxide scavenging activity of the compound was comparable with that of vitamin $C$. In reducing power assay, the activity of the compound was lower than that of vitamin $C(p>0.05)$.

Conclusion: The results of antidiabetic and antioxidant activity indicate that OXPA may be a drugcandidate for treating both diabetes and its associated oxidative stress.
\end{abstract}

Keywords: Antidiabetic, Glucose uptake, Antioxidant, Reactive oxygen species, Hemoglobin glycosylation, Alpha amylase

\begin{abstract}
This is an Open Access article that uses a fund-ing model which does not charge readers or their institutions for access and distributed under the terms of the Creative Commons Attribution License (http://creativecommons.org/licenses/by/4.0) and the Budapest Open Access Initiative (http://www.budapestopenaccessinitiative.org/read), which permit unrestricted use, distribution, and reproduction in any medium, provided the original work is properly credited.

Tropical Journal of Pharmaceutical Research is indexed by Science Citation Index (SciSearch), Scopus, International Pharmaceutical Abstract, Chemical Abstracts, Embase, Index Copernicus, EBSCO, African Index Medicus, JournalSeek, Journal Citation Reports/Science Edition, Directory of Open Access Journals (DOAJ), African Journal Online, Bioline International, Open-J-Gate and Pharmacy Abstracts
\end{abstract}

\section{INTRODUCTION}

The compound under investigation, 5-Benzyl1,3,4-oxadiazole-2-thiol (OXPA), is a derivative of 1,3,4-oxadiazole having benzyl and thiol at positions 5 and 2, respectively (Figure 1 ). It was synthesized to prepare a number of s-substituted derivatives possessing antibacterial and hemolytic activities [1]. The compound was also investigated for its behavior toward different stressors using UV spectrophotometry [2]. The compound was selected for antioxidant activity due to proton donating property of free thiol group. 
Thiol group and oxadiazole ring are the two major functional entities which can make it an antidiabetic and antioxidant drug-candidate. It is reported that thiol containing compounds act as antioxidants due to proton donating potential [35], while oxadiazole ring is a pharmacophore possessing a number of pharmacological activities including antidiabetic activity [3-5]. Therefore, OXPA is expected to have antidiabetic and antioxidant potential. An association of diabetes with oxidative stress has warranted the need to find compounds which can manage diabetes and control diabetesassociated oxidative stress, simultaneously.

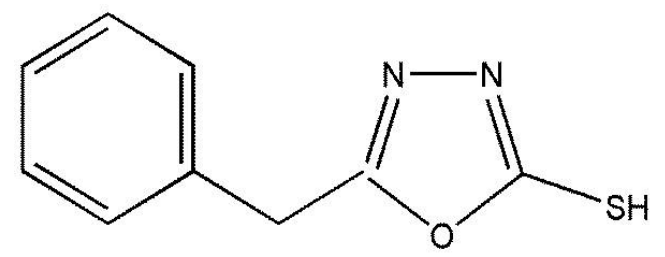

Figure 1: Chemical structure of 5-Benzyl-1,3,4oxadiazole-2-thiol (OXPA)

Diabetes is a metabolic disorder which has several etiologies including insulin deficiency, insulin resistance and genetic defects of B-cells of the pancreas. Obesity, age and lack of physical activity are also the contributors of the disorder. This disorder may be congenital Type-I diabetes - or acquired called Type-II diabetes. The prevalence of both types of the disease in all age groups is alarmingly escalating. Type-I diabetes in young-adults is reported to be 5-10\%, while 90-95\% population of the diabetics is suffering from Type-Il diabetes $[6,7]$. The complications of the disease are more fatal than the disease itself, and the same is witnessed by 1.5 million deaths due to diabetes and 2.2 million due to its co-morbidities [6,7]. These studies also indicated higher death toll in the low and middle income countries $[6,7]$.

Uncontrolled diabetes leads to hyperglycemia which results in glycosylation of blood-proteins, which causes co-morbidities such as neuropathy, retinopathy, cardiomyopathy and stroke. This situation disturbs the equilibrium between the generation of reactive oxygen species and antioxidant defense capacity [8]. The advanced glycation end products being the source of free radicals further aggravate oxidative stress [9]. Such complications can be reduced using antioxidants or compounds having both antidiabetic and antioxidant activities [10]. Therefore, the present study aimed to investigate OXPA for antidiabetic and antioxidant activities using various models.

\section{EXPERIMENTAL}

\section{Chemicals}

Glucose anhydrous (Riedel-deHaen), comercial grade baker's yeast, 2,2-diphenyl-picrylhydrazyl and disodium hydrogen phosphate (Sigma Aldrich), alpha amylase (UniChem), hydrogen peroxide $\left(\mathrm{H}_{2} \mathrm{O}_{2}\right)$, hemoglobin and potato starch (China), potassium ferricyanide, trichloroacetic acid, potassium dihydrogen phosphate, sodium dihydrogen phosphate and $\mathrm{NaOH}$ (Merck), dimethyl sulfoxide (Panreac Quimica, SAU), ascorbic acid, ferric chloride, potassium sodium tartrate and 3,5-dinitrosalicylic acid (BDH, England), acarbose (Bayer), and vitamin E (Fluka) were procured from the local market. Metronidazole (MTZ) was gifted by M/S Siza International Pvt. Ltd. Lahore, Pakistan. 5Benzyl-1,3,4-oxadiazole-2-thiol was obtained from the Department of Chemistry, Government College University, Lahore, Pakistan.

\section{Determination of anti-diabetic activity}

\section{Glucose uptake by yeast cells}

Yeast powder was washed by $0.9 \%$ ice-cold sodium chloride solution and centrifuged $(3500 \times$ $g$; $5 \mathrm{~min}$ ). The supernatant was removed and yeast cells were again washed using the same procedure until the supernatant became clear [11]. Then, yeast cell pellet was suspended in distilled water to prepare $10 \%$ (V/V) suspension. One milliliter of sample prepared in DMSO was added in test tubes containing $1 \mathrm{~mL}$ of 5,10 and $25 \mathrm{mM}$ aqueous glucose solution, and test tubes were incubated at $37^{\circ} \mathrm{C}$ for $10 \mathrm{~min}$. Then, 100 $\mu \mathrm{L}$ of the yeast suspension was added in test tubes and contents were further incubated at 37 ${ }^{\circ} \mathrm{C}$ for $60 \mathrm{~min}$. Afterwards, each tube was centrifuged for $10 \mathrm{~min}$ at $3000 \times \mathrm{g}$, and the supernatant was analyzed at $620 \mathrm{~nm}$ against a blank containing the vehicle. A control was prepared like the sample using all the components, except the test solution. Metronidazole solution, treated like the sample, served as a standard. The activity was determined using Eq. 1.

Glucose uptake $(\%)=\frac{A c-A s}{A c} \times 100 \ldots \ldots(1)$

where Ac is absorbance of control and As is absorbance of sample.

\section{Hemoglobin glycosylation inhibition activity}

The sample and reagents were prepared in 0.2 M phosphate buffer. One milliliter of 5, 10 and 25 
$\mathrm{mM}$ glucose solution was added in test tubes, separately. Then, $1 \mathrm{~mL}$ of $0.06 \%$ hemoglobin solution, phosphate buffer and sample/vitamin $\mathrm{E}$ were added in all the tubes. Finally, $5 \mu \mathrm{L}$ of 0.02 $\%$ gentamicin solution was added and the mixture was kept in the dark at room temperature. The absorbance was measured at $443 \mathrm{~nm}$ at different time intervals for $72 \mathrm{~h} \mathrm{[12]}$.

\section{Alpha amylase inhibition activity}

The activity was determined using the method described earlier [13]. The sample, standard and the enzyme dissolved in sodium phosphate buffer of $\mathrm{pH}$ 6.9. Potato-starch was suspended in phosphate buffer $(1 \%, w / v)$ and boiled for 30 min. One milliliter solution of sample, potato starch, alpha amylase $(0.025 \%$, W/ $)$ were mixed with $1 \mathrm{~mL}$ of sodium phosphate buffer $(\mathrm{pH}$ 6.9) and incubated at $37^{\circ} \mathrm{C}$ for $30 \mathrm{~min}$. Then, 0.3 $\mathrm{mL}$ of 3,5-dinitrosalicylic acid solution was added and the reaction was ceased by adding $0.2 \mathrm{~mL}$ of $2 \mathrm{~N} \mathrm{NaOH}$ and heating for $20 \mathrm{~min}$ in a water bath at $85^{\circ} \mathrm{C}$. Finally, the absorbance of the mixture was measured at $540 \mathrm{~nm}$ to calculate the alpha amylase inhibition activity.

\section{Evaluation of antioxidant activity \\ DPPH radical scavenging activity}

Three milliliters of $0.1 \mathrm{mM}$ methanolic solution of DPPH was mixed with $1 \mathrm{~mL}$ of sample/standard (ascorbic acid) and incubated in the dark at 37 ${ }^{\circ} \mathrm{C}$ for $30 \mathrm{~min}$. A blank control was prepared by replacing the sample solution with $1 \mathrm{~mL}$ of methanol. Vitamin C $(10 \mu \mathrm{g} / \mathrm{mL})$ was used as a standard. The absorbance of the sample/standard and control was measured at $517 \mathrm{~nm}$ against methanol as a blank [14].

\section{Reducing power activity}

The reducing power activity of the compound was determined using the method described earlier [15]. Briefly, a reaction mixture was prepared by mixing $1 \mathrm{~mL}$ of sample/standard solution (vitamin C), $2.5 \mathrm{ml}$ of $0.2 \mathrm{M}$ phosphate buffer $(\mathrm{pH} 6.6)$ and $2.5 \mathrm{~mL}$ of $1 \%, W / V$ potassium ferric cyanide.

The reaction mixture was kept at $50{ }^{\circ} \mathrm{C}$ in water bath for $20 \mathrm{~min}$. Then, $2.5 \mathrm{~mL}$ of trichloroacetic acid $(10 \%, W / V)$ was added and the mixture was centrifuged at $3000 \mathrm{rpm}$ for $10 \mathrm{~min}$. The supernatant $(2.5 \mathrm{~mL})$, distilled water $(2.5 \mathrm{~mL})$ and $0.1 \%, W / V$ ferric chloride solution $(0.5 \mathrm{~mL})$ were mixed and the absorbance was measured at 700 $\mathrm{nm}$.

\section{Hydrogen peroxide scavenging activity}

The sample/standard solution $(3.4 \mathrm{~mL})$ and 43 $\mathrm{mM} \mathrm{H} \mathrm{H}_{2}(0.6 \mathrm{~mL})$, prepared in phosphate buffer $(\mathrm{pH}$ 7.4), were mixed and kept at room temperature at dark for $50 \mathrm{~min}$. The absorbance of the reaction mixture was measured at $230 \mathrm{~nm}$ against phosphate buffer as a blank [16].

\section{Statistical analysis}

The samples and the standards were analyzed in triplicate and the results are presented as mean \pm standard deviation. Half maximal effective concentration $\left(E_{50}\right)$ or half maximal inhibitory concentration $\left(\mathrm{IC}_{50}\right)$ was determined applying linear regression on dose-response curves. The activity of OXPA, compared to that of standard drug, was analyzed by independent samples $t$ test using IBM, SPSS (version 20). $P<0.05$ was considered statistically significant.

\section{RESULTS}

\section{Antidiabetic activity}

The results of antidiabetic activity of OXPA using glucose uptake in yeast cells model are given in Table 1. These results showed that the compound facilitated the transport of glucose in the yeast cells in all the three glucose solutions (5, 10 and $25 \mathrm{mM})$. At equivalent concentration $(250 \mu \mathrm{g} / \mathrm{mL}$ ) activity of the compound was found to be higher than metronidazole $(p<0.05)$. The half-maximal effective concentration $\left(\mathrm{EC}_{50}\right)$ of the compound determined in a concentration range $50-250 \mu \mathrm{g} / \mathrm{mL}$ in $5 \mathrm{mM}$ glucose solution was found to be $52.77 \mu \mathrm{g} / \mathrm{mL}(\mathrm{y}=0.1121 \mathrm{x}+44.856$, $\left.R^{2}=0.9959\right)$. This indicated that activity of the compound at a concentration of $150 \mu \mathrm{g} / \mathrm{mL}$ was comparable to metronidazole $(250 \mu \mathrm{g} / \mathrm{mL})$ in 5 $\mathrm{mM}$ glucose solution. However, in 10 and $25 \mathrm{mM}$ glucose solutions, the compound at a concentration of $100 \mu \mathrm{g} / \mathrm{mL}$ showed comparable activity to that of the metronidazole $(250 \mu \mathrm{g} / \mathrm{mL})$.

The findings of hemoglobin glycosylation inhibition activity of the compound are given in Table 2. Free hemoglobin concentration decreased with the passage of time in all the three glucose, which indicated that glycosylation took place. In this assay, the activity of the compound was found to be higher as compared to vitamin $\mathrm{E}(p<0.05) . \mathrm{IC}_{50}$ of the compound determined in a concentration range (40-250 $\mu \mathrm{g} / \mathrm{mL}$ ) in 5,10 and $25 \mathrm{mM}$ glucose solutions was found to be $210.75 \mu \mathrm{g} / \mathrm{mL}$ ( $\mathrm{y}=0.1055 \mathrm{x}+$ $\left.27.788, R^{2}=0.9724\right), 125.93 \mu \mathrm{g} / \mathrm{mL}(y=0.0932$ $\left.\mathrm{x}+38.263, \mathrm{R}^{2}=0.9122\right)$ and $19.23 \mu \mathrm{g} / \mathrm{mL}(\mathrm{y}=$ $\left.0.0726 x+48.604, R^{2}=0.9828\right)$, respectively. 
These results showed that the compound inhibited the reaction of glucose and hemoglobin. Furthermore, the inhibition of glycosylation was higher in concentrated glucose solutions.

Alpha amylase inhibition activity of the compound on at a concentration of $1.4 \mathrm{mg} / \mathrm{mL}$ was $51.80 \%$, whereas acarbose at the same concentration showed $65.64 \%$ activity (Table 3 ). In this model, $\mathrm{IC}_{50}$ of the compound was found to be 1.33 $\mathrm{mg} / \mathrm{mL}\left(\mathrm{y}=36.645 x-1.6795, R^{2}=0.979\right)$. These results indicated that OXPA has a promising antidiabetic activity.

Table 3: Alpha amylase inhibition activity of 5-benzyl1,3,4-oxadiazole-2-thiol (OXPA)

\begin{tabular}{lll}
\hline Drug & Inhibition(\%) & SD \\
\hline $0.8 \mathrm{mg} / \mathrm{mL}$ & 30.01 & 1.85 \\
$1.0 \mathrm{mg} / \mathrm{mL}$ & 33.15 & 1.07 \\
$1.2 \mathrm{mg} / \mathrm{mL}$ & 39.16 & 0.95 \\
$1.4 \mathrm{mg} / \mathrm{mL}$ & 51.80 & 0.21 \\
$1.6 \mathrm{mg} / \mathrm{mL}$ & 57.33 & 0.25 \\
Acarbose & 65.63 & 0.36 \\
$(1.2 \mathrm{mg} / \mathrm{mL})$ & \\
\hline SD = standard deviation &
\end{tabular}

\section{Antioxidant activity}

The results of dose-dependent antioxidant activity of OXPA, determined using three in vitro models, are shown in Table 4. The activity of the compound was found to be comparable to the vitamin $\mathrm{C}$ in the DPPH assay $(p>0.05)$, whereas reducing power activity of the compound was less than that of vitamin $\mathrm{C}$. In hydrogen peroxide assay, activity of the compound was significantly higher than vitamin $C(p<0.05)$. The plots of concentration versus antioxidant-activity using different antioxidant-activity models were used to determine half-maximal effective concentration $\left(E_{50}\right)$. The $E_{50}$ of the compound was found to be $14.50,206.00$ and $97.00 \mu \mathrm{g} / \mathrm{mL}$ in the DPPH assay, reducing power assay and hydrogen peroxide assay, respectively. These findings showed that OXPA is a promising antioxidant drug-candidate.

\section{DISCUSSION}

The transport of glucose in yeast cells is a complex phenomenon involving some stereospecific transporters, glycolytic enzymes and concentration gradient [17-20].

Table 1: The effect of 5-Benzyl-1,3,4-oxadiazole-2-thiol (OXPA) on glucose uptake by yeast cells in glucose solutions of different concentrations

\begin{tabular}{lccc}
\hline Drug & $\begin{array}{c}\text { Activity at 5 } \mathbf{~ m M} \\
(\%)\end{array}$ & Activity at 10 $\mathbf{~ m M ~ ( \% ) ~}$ & Activity at 25 mM (\%) \\
\hline $50 \mu \mathrm{g} / \mathrm{mL}$ & $49.83 \pm 2.06$ & $61.17 \pm 3.04$ & \\
$100 \mu \mathrm{g} / \mathrm{mL}$ & $56.47 \pm 2.23$ & $63.77 \pm 1.55$ & $58.76 \pm 1.93$ \\
$150 \mu \mathrm{g} / \mathrm{mL}$ & $62.18 \pm 4.05$ & $71.09 \pm 0.48$ & $60.27 \pm 0.58$ \\
$200 \mu \mathrm{g} / \mathrm{mL}$ & $67.61 \pm 3.20$ & $72.70 \pm 0.59$ & $62.65 \pm 0.54$ \\
$250 \mu \mathrm{g} / \mathrm{mL}$ & $72.29 \pm 0.83$ & $76.80 \pm 2.64$ & $70.09 \pm 1.99$ \\
$\mathrm{MTZ} 250 \mu \mathrm{g} / \mathrm{mL}$ & $64.03 \pm 1.23$ & $61.97 \pm 2.74$ & $60.71 \pm 2.31$ \\
\hline
\end{tabular}

$M T Z=$ metronidazole

Table 2: Hemoglobin glycosylation inhibition activity of 5-Benzyl-1,3,4-oxadiazole-2-thiol (OXPA)

\begin{tabular}{lccc}
\hline Drug & Activity at 5 mM (\%) & Activity at 10 mM (\%) & Activity at 25 mM (\%) \\
\hline $50 \mu \mathrm{g} / \mathrm{mL}$ & $33.83 \pm 1.78$ & $44.83 \pm 2.53$ & $51.63 \pm 1.44$ \\
$100 \mu \mathrm{g} / \mathrm{mL}$ & $38.73 \pm 2.06$ & $47.29 \pm 2.30$ & $56.84 \pm 0.99$ \\
$150 \mu \mathrm{g} / \mathrm{mL}$ & $42.06 \pm 2.76$ & $49.84 \pm 2.53$ & $59.67 \pm 0.88$ \\
$200 \mu \mathrm{g} / \mathrm{mL}$ & $47.48 \pm 3.12$ & $54.93 \pm 2.15$ & $62.20 \pm 0.14$ \\
$250 \mu \mathrm{g} / \mathrm{mL}$ & $55.83 \pm 1.19$ & $64.31 \pm 1.10$ & $67.09 \pm 0.71$ \\
Vitamin-E & $40.31 \pm 1.39$ & $49.03 \pm 2.00$ & $58.30 \pm 0.38$ \\
\hline
\end{tabular}

Table 4: Antioxidant activity of 5-benzyl-1,3,4-oxadiazole-2-thiol (OXPA) based on three models $(n=3)$

\begin{tabular}{|c|c|c|c|c|c|}
\hline $\begin{array}{l}\text { Drug } \\
(\mu \mathrm{g} / \mathrm{ml})\end{array}$ & $\begin{array}{c}\text { DPPH assay } \\
\text { (mean } \pm S D)\end{array}$ & $\begin{array}{l}\text { Drug } \\
\mu \mathrm{g} / \mathrm{ml}\end{array}$ & RPA (mean $\pm S D$ ) & $\begin{array}{l}\text { Drug } \\
\mu \mathrm{g} / \mathrm{ml}\end{array}$ & HPO (mean \pm SD \\
\hline 5 & $27.7 \pm 1.20$ & 50 & $29.0 \pm 0.40$ & 20 & $22.0 \pm 0.50$ \\
\hline 10 & $37.5 \pm 1.60$ & 100 & $33.8 \pm 1.40$ & 40 & $32.1 \pm 0.50$ \\
\hline 25 & $76.2 \pm 0.10$ & 150 & $38.8 \pm 0.90$ & 80 & $43.3 \pm 0.20$ \\
\hline 50 & $92.3 \pm 0.90$ & 200 & $49.3 \pm 0.20$ & 100 & $50.9 \pm 0.90$ \\
\hline 100 & $92.9 \pm 0.70$ & 250 & $63.6 \pm 0.30$ & 150 & $59.3 \pm 0.60$ \\
\hline S 10 & $33.2 \pm 0.40$ & $S 250$ & $84.9 \pm 0.10$ & S 80 & $28.4 \pm 0.60$ \\
\hline
\end{tabular}


Glucose transport was found to be higher in concentrated glucose solutions, which indicated that higher glucose concentration and glucose utilization in fermentation had facilitated glucose influx in yeast cells. Moreover, the influx was faster in 5 and $10 \mathrm{mM}$ glucose solutions as compared to $25 \mathrm{mM}$ glucose solution. The reason of slow glucose uptake in $25 \mathrm{mM}$ glucose solution could be due to decreased activity of the transporters as a result of establishing equilibrium between intracellular and extracellular glucose concentration. These results are consistent with that reported earlier indicating that intracellular glucose concentration during its uptake inhibits the glucose-influx and in some cases, promotes efflux $[17,18]$.

Glycosylated hemoglobin ( $\mathrm{HbA1c}$ ) is produced by an increased blood-glucose concentration. Glycosylation of hemoglobin results in the formation of reactive oxygen species which cause diabetes-associated complication [8]. The literature review indicated that terminal nitrogen of valine of hemoglobin is glycosylated with glucose [21]. In the present study, OXPA inhibited the glycosylation of hemoglobin that might be due to the interaction of nitrogen atoms of the oxadiazole ring with glucose. Digestive enzymes such as alpha-amylase and alphaglucosidase convert starch into glucose and maltose in the intestine [22]. Therefore, the inhibitors of such enzymes (acarbose, voglibose and miglitol) are used to manage Type-II diabetes [23]. In the present study, the compound inhibited the alpha-amylase activity significantly, which indicated that OXPA may be used to decrease glucose availability from the intestine from digestible carbohydrates, hence may be used as an oral anti-hyperglycemic agent.

Antioxidants act through various mechanisms, therefore, in the present study, antioxidant potential of the compound was evaluated using three antioxidant models. The DPPH free radical is reduced by proton donors. Thiol group of the compound can donate proton, therefore, DPPH free radical scavenging may be due to proton of the thiol group. DPPH scavenging activity of the compound was comparable with vitamin $\mathrm{C}$ (standard drug). Likewise, the compound showed promising antioxidant activity in reducing power assay. In this assay, the compound reduced the ferric to ferrous that was indicated by change of color. Thiol group may chelate ferric ions as reported earlier that such group containing compound chelate metals [24]. Therefore, hydrogen donating capacity and metal chelation are expected to be the mechanism of antioxidant activity of the compound. Hydrogen peroxide
$\left(\mathrm{H}_{2} \mathrm{O}_{2}\right)$ scavenging activity of the compound indicated its usefulness in the living system. In the living system, hydrogen peroxide formed by biological processes produces highly toxic hydroxyl radical that can attack many cellular energy-producing glycolytic enzyme. Therefore, the tendency of thiol containing compounds in scavenging of $\mathrm{H}_{2} \mathrm{O}_{2}$ is very important for protecting living organisms from the oxidative stress. The unsaturation of the compound may also be involved in scavenging $\mathrm{H}_{2} \mathrm{O}_{2}$ as reported earlier $[24,25]$. Antioxidants help in preventing diabetes-associated complications. As stated earlier that thiol group makes OXPA a strong reducing agent. Hence, the compound may be an effective antioxidant and antidiabetic agent.

\section{CONCLUSION}

The results of the present study indicate that 5benzyl-1,3,4-oxadiazole-2-thiol (OXPA) has antidiabetic activity by acting via the various mechanisms. Moreover, the compound has antioxidant potentials which is comparable to that of vitamin C. Therefore, OXPA may be beneficial in managing diabetes and reducing oxidativeinduced co-morbidities.

\section{DECLARATIONS}

\section{Acknowledgement}

SQ is thankful to Dr. Quaid Zaman, Assistant Professor, University of Veterinary and Animal Sciences, Lahore, Pakistan, for providing laboratory facilities to perform hemoglobin glycosylation studies.

\section{Conflict of interest}

No conflict of interest is associated with this work.

\section{Contribution of authors}

We declare that this work was done by the authors named in this article and all liabilities pertaining to claims relating to the content of this article will be borne by the authors. KH and NIB conceived and designed the study. SZS, AR and MAA synthesized the compound and NS checked it purity. SP, AL, MI, SN and EA helped in performing the experiments. The manuscript was drafted by SQ and reviewed by $\mathrm{KH}$ and NIB.

\section{Open Access}

This is an Open Access article that uses a funding model which does not charge readers or their 
institutions for access and distributed under the terms of the Creative Commons Attribution License (http://creativecommons.org/licenses/by/ 4.0) and the Budapest Open Access Initiative (http://www.budapestopenaccessinitiative.org/rea d), which permit unrestricted use, distribution, and reproduction in any medium, provided the original work is properly credited.

\section{REFERENCES}

1. Siddiqui SZ Aziz-ur-Rehman, Abbasi MA, Abbas N, Khan KM, Shahid M, Mahmood Y, Akhtar MN, Lajis NH. Synthesis, antibacterial screening and hemolytic activity of s-substituted derivatives of 5-benzyl-1,3,4-oxadiazole2-thiol. Int J Pharm Pharm Sci 2012; 4(2): 676-680.

2. Qamar S, Hussain K, Bukhari NA, Shehzadi N, Islam M, Siddique SZ, Rehman A. Method development and stress degradation profile of 5-benzyl-1,3,4-oxadiazole2-thiol studied by UV-Spectroscopy. Pharm Chem J 2018; 52(3): 278-284.

3. Iqbal AKM, Khan AY, Kalashetti MB, Belavagi NS, Gong YD, Khazi IAM. Synthesis, hypoglycemic and hypolipidemic activities of novel thiazolidinedione derivatives containing thiazole/triazole/oxadiazole ring. Eur J Med Chem 2012; 53: 308-315.

4. McCoull W, Addie MS, Birch AM, Birtles S, Buckett LK, Butlin RJ, Bowker SS, Boyd S, Chapman S, Davies RD, et al. Identification, optimisation and in vivo evaluation of oxadiazole DGAT-1 inhibitors for the treatment of obesity and diabetes. Bioorg Med Chem Lett 2012; 22: 3873-3878.

5. Kikkeri NM, Chikkur BPK. Synthesis and antioxidant activity of 2-Amino-5-methyl thiazol containing 1,3,4oxadiazole-2-thiol moiety. Organic Chem 2013; 2013: 18.

6. Position statement. American diabetes association. Diagnosis and classification of diabetes mellitus. Diabetes Care, 31(1). 2008, S62-S67.

7. WHO, World Health Organization, Global Report on Diabetes, 2016; apps.www.who.int/mediacentre/fact sheets/fs312/en/;access on January 12, 2018.

8. Spadiene $N$, Savickiene L, Ivanauskas $V$, Jakstas $A$, Skesters, Silova A. Antioxidant effects of Camellia sinensis L. extract in patients with type 2 diabetes. J. Food Drug Anal 2014; 22: 505-5011.

9. Vijay $P$, Vimukta $S$. The role of natural antioxidants in oxidative stress induced diabetes mellitus. Res $J$ Pharm Sci 2014; 3(4): 1-6.

10. Aruoma OI. Free radicals, oxidative stress, and antioxidants in human health and disease. J Am Oil Chem Soc 1998; 75(2): 199-212.

11. Cirillo VP. Mechanism of arabinose transport in Tetrahymena pyriformis. J. Bacteriol 1962; 84(3): 485491.
12. James $S A$, Auta R, Goje DJ. In vitro study on inhibition of glycosylation of methanolic leaf extract of Hibiscus cannabinus. Sci World J 2011; 6(3): 7-9.

13. Giancarlo S, Rosa LM, Nadjafi $F$, Francesco $M$. Hypoglycaemic activity of two spices extracts: Rhus coriaria L. and Bunium persicum Boiss. Nat Prod Res 2006; 20(9): 882-886.

14. Brand-Williams W, Cuvelier ME, Berset C. Use of free radical method to evaluate antioxidant activity. Lebensm Wiss U Technol 1995; 28: 25-30.

15. Oyaizu M. Studies on product of browning reaction prepared from glucose amine. Jpn J Nut 1986; 44(6): 307-315.

16. Ruch RJ, Cheng SJ, Klaunig JE. Prevention of cytotoxicity and inhibition of intracellular communication by antioxidant catechins isolated from Chinese green tea. Carcinogenesis 1989; 10(6): 1003-1008.

17. Teusink B, Jasper A, Diderich HV, Westerhoff DKV, Walsh MC. Intracellular glucose concentration in derepressed yeast cells consuming glucose is high enough to reduce the glucose transport rate by $50 \%$ J Bacteriol 1998; 180: 556-562.

18. Terkuile BH, Opperdoes FRJ. Glucose uptake by Trypanosoma brucei, rate limiting steps in glycolysis and regulation of the glycolytic flux. Biol Chem 1991; 266: 857-862.

19. Stein WD. Transport and Diffusion Across Cell Membranes, Academic Press, London; 1986; $p 704$.

20. Walsh MC, Smits HP, van Dam K. Glucose sensing and signaling properties in Saccharomyces cerevisiae require the presence of at least two members of the glucose transporter family. J Bacteriol. 1996; 178(9): 2593-2597.

21. Haney DN, Bunn HF. Glycosylation of hemoglobin in vitro: Affinity labeling of hemoglobin by glucose-6phosphate (hemoglobin modification/diabetes mellitus/hemoglobin Aic/2, 3-diphosphoglycerate/ glycoprotein). Proc Natl Acad Sci USA 1976; 73(10): 3534-3538.

22. Bhat M, Zinjarde SS, Bhargava SY, Kumar AR, Joshi BN. Antidiabetic Indian plants, a good source of potent amylase inhibitors. Evid Based Complement Alternat Med 2011; 810207: Doi: 10.1093/ecam/nen040.6 pages.

23. Winterbourn CC, Metodiewa $D$. The reaction of superoxide with reduced glutathione. Arch Biochem Biophys 1994; 314: 284-290.

24. MacDonald-Wicks LK, Wood LG, Garg ML. Methodology for the determination of biological antioxidant capacity in vitro: a review. J Sci Food Agric 2006; 86: 2046-2056.

25. Hyslop PA, Hinshaw DB, Halsey WA, Schraufstatter JIU, Sauerhebery RD, Spraggj RG, Jackson JH, Cochrane CG. Mechanisms of oxidant mediated cell injury. J Biol Chem 1988; 263: 1665-1675. 